\title{
Comparing ion torrent with pyrosequencing and Sanger sequencing for the detection of TP53 mutations in colorectal cancer
}

\author{
Brendan Doyle ${ }^{1 *}$, Clarence C Lee ${ }^{2}$, Timothy T Harkins ${ }^{2}$, Rosella Petraroli², Paul Smyth ${ }^{1}$, Kieran Sheahan ${ }^{3}$, \\ John J O'Leary', Orla Sheils ${ }^{1}$
}

From EPMA-World Congress 2013

Brussels, Belgium. 20-21 September 2013

\section{Scientific objectives}

The detection of mutations in tumour tissue is increasingly important to pathologists due to the number of targeted, personalised therapies that are only effective in tumours displaying specific mutations. At present, much of the testing to detect these mutations is performed using individual assays. This has proven to be an effective method as the number of 'drugable' mutations is currently relatively low. However, the number of targeted therapies (and therefore targets to be assessed) is expected to rise significantly. This has led to the development of assays capable of assessing mutations across multiple gene panels. Here we assess one new technology (Ion Torrent's PGM), comparing the results to those obtained with pyrosequencing and Sanger sequencing, both established technologies used in molecular pathology laboratories.

\section{Technological approach}

DNA extracted from 8 cell lines with known TP53 mutations (CCRF-CEM, SW 837, NCI-H23, U251, MDAMD231, SKBR-3, CALU6, C33a) was sequenced using Ion Torrent (Ion PGM sequencer, Life Technologies), Pyrosequencing (PyroMark Q24, Qiagen) and Sanger sequencing technology.

\section{Results}

The Ion Torrent results matched those achieved using pyrosequencing and Sanger sequencing in all 8 cases. The results also matched the known mutations for these cell lines in the TP53UMD mutation database.

* Correspondence: doyleb4@tcd.ie

1 Department of Histopathology, Trinity College Dublin, Ireland

Full list of author information is available at the end of the article

\section{Conclusion and recommendations}

Results achieved with the Ion Torrent PGM were comparable to those seen using pyrosequencing and Sanger sequencing. As the number and complexity of tests required to inform clinicians increases technologies such as this, with high throughput and scope for expansion may prove beneficial to diagnostic molecular pathology laboratories.

\section{Authors' details}

'Department of Histopathology, Trinity College Dublin, Ireland. ${ }^{2}$ Life Technologies, Foster City, CA, USA. ${ }^{3}$ Department of Histopathology, St. Vincent's University Hospital, Dublin, Ireland.

Published: 11 February 2014

doi:10.1186/1878-5085-5-S1-A32

Cite this article as: Doyle et al: Comparing ion torrent with

pyrosequencing and Sanger sequencing for the detection of TP53 mutations in colorectal cancer. EPMA Journal 2014 5(Suppl 1):A32.

Submit your next manuscript to BioMed Central and take full advantage of:

- Convenient online submission

- Thorough peer review

- No space constraints or color figure charges

- Immediate publication on acceptance

- Inclusion in PubMed, CAS, Scopus and Google Scholar

- Research which is freely available for redistribution

Submit your manuscript at www.biomedcentral.com/submit 